\title{
Management of Lime in Steel
}

\author{
Sanjeev Manocha ${ }^{1}$ and François Ponchon ${ }^{2, *}$ \\ 1 Carmeuse Group, 1348 Louvain-la-Neuve, Belgium; sanjeev.manocha@carmeuse.com \\ 2 Carmeuse Europe, 1348 Louvain-la-Neuve, Belgium \\ * Correspondence: francois.ponchon@carmeuse.com; Tel.: +32-10-481-694
}

Received: 4 July 2018; Accepted: 28 August 2018; Published: 31 August 2018

\begin{abstract}
The EU28 total lime demand in 2017 was estimated at about 20 million tons, out of which about $40 \%$ are consumed in the iron and steel industry. Steel remains the major consumer after environment and construction. The lime industry is quite mature and consolidated in developed countries, with enough reserves and production to serve regional markets while being fragmented in developing nations where steel producers rely on local sourcing. There is relatively very little trade for lime worldwide. Lime has a critical role at different steps of the steelmaking process, and especially to make a good slag facilitating the removal of sulphur and phosphorus, and for providing a safer platform to withstand high intensity arc plasma in the electric arc furnace (EAF), and violent reactions in the basic oxygen furnace (BOF). Lime quality and quantity has a direct effect on slag quality, which affects metallurgical results, refractory life, liquid metal yield, and productivity, and therefore the total cost of the steel production. In this paper, we present the importance of careful selection in the limestone and calcination process, which influences critical lime quality characteristics. We shall further elaborate on the impact of lime characteristics in the optimization of the steelmaking process, metallurgical benefits, overall cost impact, potential savings, and environmental benefits.
\end{abstract}

Keywords: lime; slag; cost; savings; quality

\section{Introduction}

Despite the development of many new industries using lime, the steel industry today remains the major consumer, consuming almost half of the annual lime production. Most of the steel processes involve the use of lime as a flux. Industrial lime production today allows the quality adapted to the needs of different steel applications to be reached. Even if the cost of lime has relatively little impact on the cost of steel, lime quality can have a significant impact on the steel quality, its metallurgical properties, productivity, and the total cost of production. The steel industry is indeed facing different issues related to the ever-growing demand for cleaner steel, for example in the automotive industry, while it is being pushed to reduce its impact on the environment from managing by-products and taking measures to mitigate $\mathrm{CO}_{2}$ emissions and energy use. Lime quality that is adapted to the use in steel industry is then a very important subject to allow the market demand to be met in the longer term.

\section{Lime Supply in Steel Outlook}

Lime is a product of calcination of limestone that is extracted from quarries. Quality and access to limestone sources is then the key to be able to produce quality lime that is suitable for industries such as steel.

It is rather easy to find figures about how much limestone or dolostone reserves exist in each part of the world, but it is hard to find global data about the specific limestone that is suitable to make lime, considering the hardness of the stones, calcium content, and low impurities. Furthermore, limestone resources are not all easily accessible, due to urbanistic pressure, permissions, environmental 
constraints, and infrastructure. For example, there are plenty of good limestone deposits in Western Europe, but acquiring permission is very long and restrictive. There are rare low-grade deposits in India with high urbanistic pressures and relatively bad logistics. There are localized high-grade limestone deposits in Brazil, Argentina, Thailand, Vietnam, or Malaysia with medium urbanistic pressures, and sometimes very restrictive and variable permission processes for the environment. There are a plenty of high-grade limestone deposits in China, but these are not accessible to foreigners.

The world production of lime is estimated at around 350 million tons. Steel uses between 140 and 160 million tons of lime globally. A big part of lime production is captive produced within steel mills, especially in the developing world. EU28 lime production is estimated at about 20 million tons, of which about 8 million tons are consumed in the iron and steel industry. China produces around 230 million tons of lime, and the estimated volume used in steel is 70 million tons. USA produces 18 million tons, out of which about 7 million tons is used in steel applications.

\section{Quality Lime Production for Steel Applications}

Derived from limestone, lime has several natural properties that are useful in various industrial domains. Being produced and used since the prehistoric ages, the use of lime in steel has been known for many centuries. The industrial production of lime started at the same time as modern steel production, in the late 19th century. To have a better understanding of the importance of lime properties, it is useful to describe more in detail the different steps of production of lime, from the raw material to engineered products that are adapted for use in the iron- and steelmaking processes.

\subsection{Limestone Quality}

Limestone is obviously the starting point for lime production. Literally, limestone is "the stone to be used to make lime". Limestone deposit occurrences are wide, and reserves around the world are abundant. Nevertheless, there is a first limitation to access to this product in some countries because of difficulties with getting permission for exploiting a quarry or a mine, due to environmental rules and the social acceptability related to the modification of the landscape, induced impacts like dust generation, or potential underground water pollution. Moreover, the cost of transport can have a big impact on the full cost, due to the relative low price of the material. Dolomite stone is used to produce burnt dolomitic lime (dolime, as mentioned in rest of the document). The occurrence of dolomite deposits is much less important, which leads to only specific plants having access to, and using dolime.

Limestone is a sedimentary rock that usually originates from the progressive accumulation and cementation of inorganic and organic carbonate grains, such as ooids, peloids, crinoids (sea lilies), shells, algae, corals, and various micro-organisms on the sea floor, and during subsequent burial. Limestone actually describes a big family rocks of different crystallinities and textures. Dissolution and precipitation with carbonic acid leads to a dense crystallized stone with more or less density. Chalk as an example, is a fully bioclastic limestone that contains an accumulation of micrometric coccolites, and due to these particular microstructures, the petrophysical properties (density, porosity) are generally low, whereas marble is a metamorphic, highly crystalline rock with higher density. It is worth mentioning here that not all types of limestone are indeed suitable for use in the calcination step, due to their chemical contents and microstructural properties [1]. The physical and chemical properties of raw stone significantly affect the final properties of calcined lime and dolime.

Limestone crystallinity and texture has a significant impact on both stone processing and affects the behavior of the calcination step. Soft stones usually generate more limestone fines, which is a major issue for production balance in lime kilns. Stone porosity may vary due to presence of interstices such as crevices. During the calcination process, the stone will first expand already during the preheating stage, which can cause breakages. At higher temperatures, de-carbonation will lead to lower density and shrinkage, and increased gas pressure inside the matter. Fissures such as expansion joins can then form, generating internal stress and breakages. There are types of limestone, which are practically are not possible to calcine into lump or pebble quicklime, but will only end up with fines. It is almost 
impossible to predict this behavior, which is called decrepitation, without experimenting on the effect of heat on the stone integrity [1,2].

To illustrate, we recently conducted various laboratory-based trials, followed by industrial trials, to qualify the limestone that was suitable for calcination, either in a parallel flow regenerative (PFR) shaft kiln or in a rotary kiln, with or without a preheater. The laboratory tests raised the concern about limestone fines and the sticking tendency in the kilns. The industrial trial results clearly reflected the lab results (higher fines) at the entry point of the kilns contributed to the limestone characteristics, while particle size distribution (PSD) as measured at the run of the rotary kiln, did not reveal any significant differences after calcination. The sticking tendency (Figure 1) became a major concern in the PFR kiln. Similar trials in the rotary kiln revealed no sticking in the rotary kiln. A rotary kiln with a preheater generated significantly lower amounts (50\% reduction) of lime kiln dust (LKD), compared to one without preheaters.

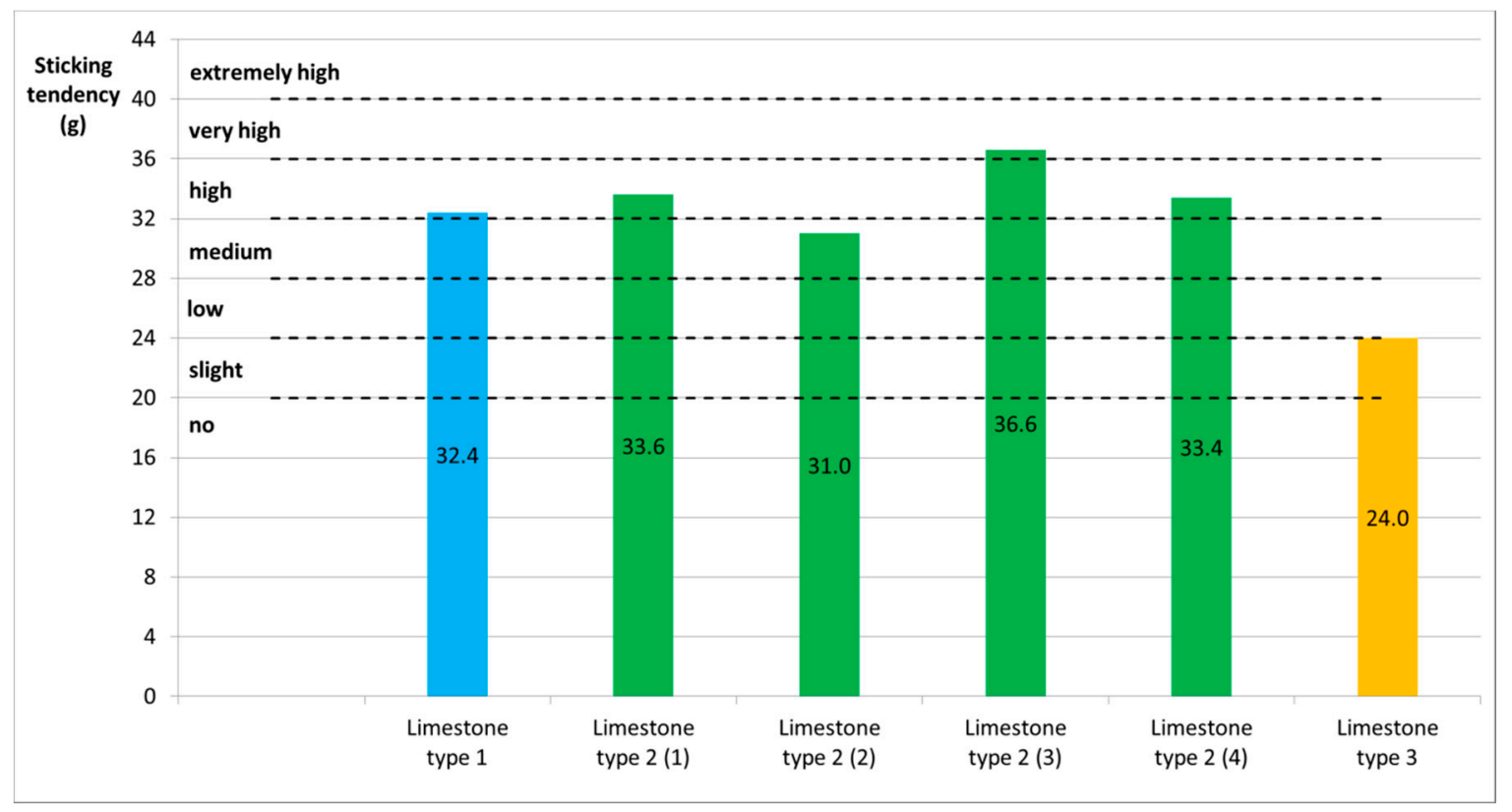

Figure 1. Sticking tendency of lime calcined from three types of limestones (ㄷ Carmeuse).

Limestone chemical purity has a direct effect on the chemical purity of lime. There are some possibilities for removing the impurities when they are principally located around the stone, but otherwise further processing steps will keep the impurities embedded with the finished product. The main impurities in limestone are in the form of clay, silt, or sand, or sometime organic matter. The calcium $(\mathrm{Ca})$ and carbon dioxide $\left(\mathrm{CO}_{2}\right)$ constitute the calcium carbonate $\left(\mathrm{CaCO}_{3}\right)$, with impurities including $\mathrm{Mg}, \mathrm{Si}, \mathrm{Al}, \mathrm{S}, \mathrm{P}, \mathrm{K}$, and $\mathrm{Na}$. A metallurgical grade of stone would require already a minimum of $95 \%$ carbonates ( $\mathrm{Ca} \& \mathrm{Mg}$ ).

Limestone is usually extracted from open-air quarries rather than underground mines, thanks to an outcrop of quality products in most of the deposits. Nevertheless, it is common that good chemical quality occurs only in certain layers, raising the need to select and separate aggregate types from the chemical stone to be calcinated. We can cite, for example, a fascinating selective underground mine located in Brembilla (Italy), where limestone is mined in big chambers of 180 to $200 \mathrm{~m}$ depth, $100 \mathrm{~m}$ in height, and $30 \mathrm{~m}$ in width, interconnected by tunnels for the access and evacuation of stones through conveyers belts.

Limestone extraction is done by blasting, followed by crushing and screening. Depending on the chemical characteristics, limestone can be washed to remove the surrounding impurities such as clays. 
Calibrated stones size depends on the kiln type [3]. Finer-sized limestone can be used partially as raw material for self-fluxing sinters.

\subsection{Calcination}

Starting from the calibrated limestone $\left(\mathrm{CaCO}_{3}\right)$, lime is obtained by burning at high temperature to produces high-calcium lime $(\mathrm{CaO})$ and carbon dioxide $\left(\mathrm{CO}_{2}\right)$, followed by the decarbonation reaction, which occurs at a temperature of between 800 and $1000{ }^{\circ} \mathrm{C}\left(700-900{ }^{\circ} \mathrm{C}\right.$ for dolomitic lime):

$$
\begin{gathered}
\left.\mathrm{CaCO}_{3}+\text { heat }=\mathrm{CO}_{2}+\mathrm{CaO} \text { (high calcium lime }\right) \\
\mathrm{CaCO}_{3} \cdot \mathrm{MgCO}{ }_{3}+\text { heat }=\mathrm{CO}_{2}+\mathrm{CaO} \cdot \mathrm{MgO}(\text { dolime })
\end{gathered}
$$

The calcination process occurs in industrial kilns under controlled conditions with adapted technology. Since the early 20th century, almost countless variations of kilns have been invented and promoted [2]. Broadly, modern kilns that are used to produce lime for steel application can be classified into two main categories: vertical kilns and rotary horizontal kilns (Figure 2). Vertical kiln technology is the oldest technology, being used since the first industrial production of lime, and these kilns are still existent and the most widely used types, thanks to many technical improvements, especially those that are related to energy efficiency improvement, $\mathrm{CO}_{2}$ output, and operational and maintenance costs. Rotary kilns are also still used and are equipped with preheaters, coolers, and heat exchangers.

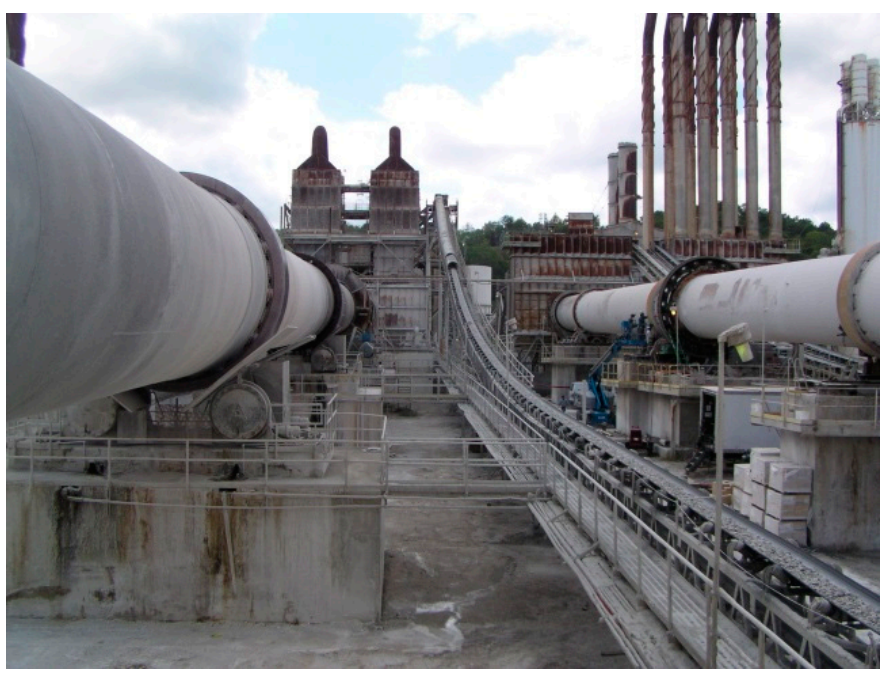

(a)

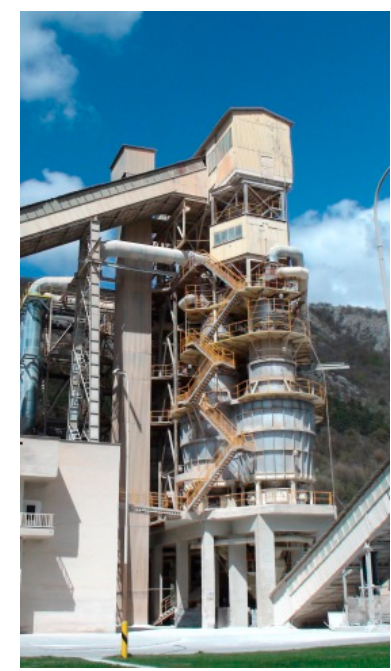

(b)

Figure 2. Lime kilns. (a) Rotary kiln. (b) Vertical kiln (@ Carmeuse).

The vertical kiln working principle is an annular vertical shaft that is fed by limestone from the top. Air is fed from the bottom and heated progressively in the counter-direction. Fuel can either be added along with limestone, or burned with lances inside the kiln. Different phases occur in the kiln: in the top part, limestone is preheated by hot air coming from the lower layers; in the median part, preheated limestone is calcinated (de-carbonated) at a temperature of around $900{ }^{\circ} \mathrm{C}$; in the lower part, lime is cooled by fresh air entering the kiln. An improvement of this process is called the parallel flow regenerative (PFR) kiln, which consists in two or three independent shafts running alternatively and exhausting the heated gas to the stone charge of the other(s) shaft(s). Today, this is still the best available technology regarding both lime quality and production efficiency $[4,5]$.

Rotary kilns are inspired from cement production-type kilns, but they run at lower temperatures, in the range of 900 to $1300{ }^{\circ} \mathrm{C}$. The working principle is a horizontal rotating drum with a small incline. Limestone is fed on the one side, and a heater is placed at the opposite side for hot air to circulate 
upfront. Such kilns have some advantages, such as big potential production capacities, easy adjustment of the process by adjusting the speed, and the possibility for using finer stone sizes and a wider quality of fuels. However, the calorific yield of such kilns remains very high compared to enhanced vertical kiln technologies.

The fuels used are dependent on the kiln type. Solid fuels such as coal or coke can be used in vertical kilns, fed together with limestone. Liquid and gaseous fuels, including natural gas, are burned through lances positioned two-thirds of the way up the shaft length. Alternative fuels like wood or other secondary fuels can also be used, but they must be monitored carefully regarding the risk of pollutants and impurities being transferred to lime, like for example, sulphur.

\subsection{Lime Quality for Steel Processes}

Lime to be used in the steel melting process depends on the application; limestone and lime are indeed used in different forms at different steps of the steelmaking process. Lime is used during agglomeration before sintering, for balancing the acidity and as a component in desulphurization, but most of the volume is used as a fluxing agent, meaning that the slag properties and chemistry are modified in the basic oxygen furnace (BOF) converter or in the electric arc furnace (EAF), and during the secondary metallurgy/ladle refining (LF) process.

The following principal characteristics are important when qualifying lime for steel [6]:

- Chemical composition and degree of calcination

- Reactivity

- Grain size

- Uniformity

\subsubsection{Chemical Composition and Degree of Calcination}

The chemical content of lime (Figure 3) is a key parameter. As mentioned above, limestone chemistry has a significant effect on lime chemistry, especially for the main impurities [7]. Calcination also influences the resulting chemistry, and especially the $\mathrm{CO}_{2}$ remaining content, due to incomplete calcination $\left(\mathrm{CaCO}_{3}\right.$ remaining) and the $\mathrm{S}$ content principally coming from the fuel. $\mathrm{CO}_{2}$ is measured using loss of ignition (LOI) at $1000{ }^{\circ} \mathrm{C}$, or by the infrared induction system, which also allows for $\mathrm{S}$ measurement. Other impurities like $\mathrm{SiO}_{2}, \mathrm{Al}_{2} \mathrm{O}_{3}, \mathrm{Fe}_{2} \mathrm{O}_{3}$, and $\mathrm{MgO}$ are measured with calibrated X-Ray Fluorescence (XRF).

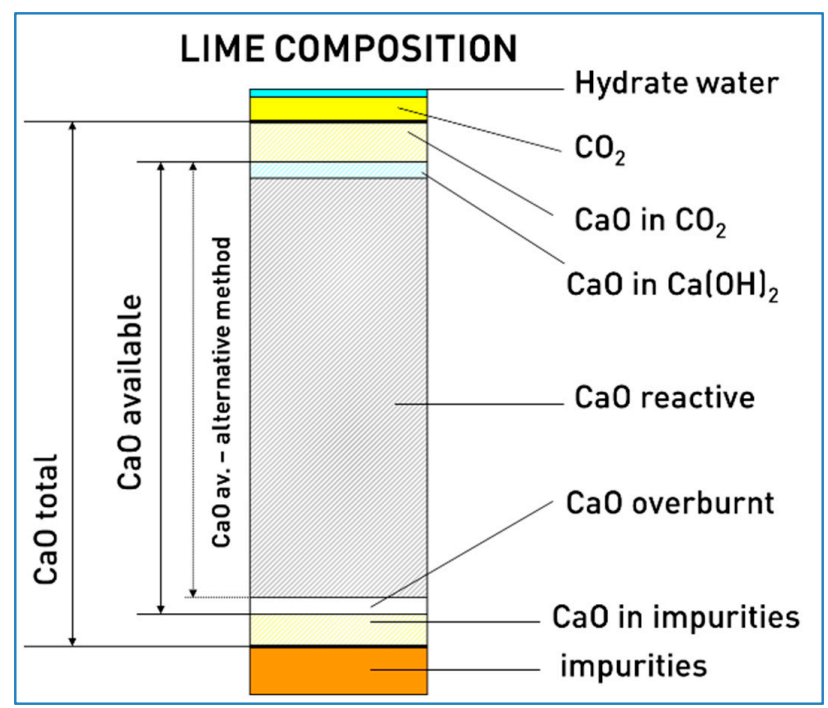

Figure 3. Lime composition. 
$\mathrm{SiO}_{2}$ should be as low as possible, as it can combine with $\mathrm{CaO}$ to form insoluble crystals. $\mathrm{Fe}_{2} \mathrm{O}_{3}$ and $\mathrm{Al}_{2} \mathrm{O}_{3}$ have favorable effects on the lime dissolution in slag, but they are generally available only in small quantities in limestone. Ideally, the sulphur should be as low as possible to avoid pick-up in the steel, but it is compromised, depending on the steel grade, and economic or availability reasons.

Magnesium oxide $(\mathrm{MgO})$ content of lime is of increasing importance in $\mathrm{BOF}$ and EAF. There is a favorable influence of lime containing $\mathrm{MgO}$ on the refractory lining life of the converter. Combined addition of high calcium quicklime and dolime is a usual practice in EAF.

Loss of ignition comprising $\mathrm{CO}_{2}$ (from calcium carbonate) and $\mathrm{H}_{2} \mathrm{O}$ (from hydrated lime) must be as low as possible. Hydrated portions in the lime reduce its reactivity, and may increase the risk of hydrogen inclusions in the steel. Special attention is required to keep control of calcination and its use, by appropriate storage and handling conditions.

\subsubsection{Reactivity}

Another important parameter of lime is so-called reactivity. Reactivity of lime for the steel industry is considered to be the efficacy of lime for dissolving in the slag. This is met by reactive lime, which has small size crystals and high porosity [8]. This parameter is usually approached by measuring its reactivity with water or with acids such as hydrochloric acid $(\mathrm{HCl})$. Lime reactivity in water can be measured following the European standard EN 459-2. The result of this analysis remains only an indication about the capacity of the lime to react with the slag, since the slag is an ionic solution of molten salts, and thus behaves in a completely different way to water [9].

Depending on the amount of impurities in the limestone, and its texture combined with the type of fuel used, the reactivity of burnt lime will vary [10]. Overburning of the lime will influence the porosity of the lime and reduce its reactivity. There is always a compromise to obtaining a high reactivity, with unburnt carbonate being located in the center of the stone [11]. Homogenous spreading of the stones, stone advance in the kiln, and uniform heating, are also key parameters to reaching high reactivity and low $\mathrm{CO}_{2}$. Anyhow, reactivity just after calcination also influences the stability of the lime, which can capture the humidity of the air with the creation of fines, are re-carbonated, and thus have a lower reactivity during usage [12].

\subsubsection{Grain Size}

Lime gradation is also an important parameter for to allowing its use under good conditions, and for obtaining the best possible yield.

For example, in conventional BOF use, lime is dropped into the furnace using a scrap bucket or conveyors. There is a risk of fines being sucked in by the de-dusting system. A high percentage of fines then causes lime losses in the waste gases, and further problems in dust treatment. Steel industry customers usually ask for products in a size range of 5 to $60 \mathrm{~mm}$, with a requirement of less than $10 \%$ of fines below $5 \mathrm{~mm}$. Some steel plants even requests less fines in the specifications, considering the generation of fines in their own processes from storage to application (Table 1). The decision on grading and the fines content of lime and dolime is primarily based on the furnace behavior, such as negative pressure and dissolution time, and also on the $\mathrm{CaO}$ content in the dust, and the commercial availability. The use of briquettes of lime is also a way to use the fines, and offers a very reactive product without the issue of dust.

Another example is the use of pulverized quicklime at the desulphurization step by co-injection with Mg metal or calcium carbide. This product must have a specific grain size, and it is modified by additives to enhance its flowability, for perfect injection properties. 
Table 1. Example of lime specifications for the basic oxygen furnace (BOF).

\begin{tabular}{ccc}
\hline Specification & Steel Plant 1 & Steel Plant 2 \\
\hline $\mathrm{CaO}(\min . \%)$ & 92 & 95 \\
$\mathrm{SiO}_{2}(\max \%)$ & 2.5 & 1.0 \\
$\mathrm{~S}(\max \%)$ & 0.04 & 0.05 \\
Grading & 3.0 & 3.0 \\
Fine content & $10-30 \mathrm{~mm}$ & $12-38 \mathrm{~mm}$ \\
Reactivity & $10 \% \mathrm{max} .<5 \mathrm{~mm}$ & $5 \%$ max. $<2 \mathrm{~mm}$ \\
\hline
\end{tabular}

\subsubsection{Uniformity}

Like in any industrial application, increased attention is paid to the uniformity of the lime qualities. Lime quality variation not only leads to excess dosing and deterioration of the chemical-physical conditions, but it also disturbs the control of the refining process. We will further develop the importance of lime quality in the steel process.

Powdered quicklime can be used in new systems using lances. It is mainly installed today in EAF systems, together with lances for $C$ injection. It allows both a better yield during use, and better efficiency in the slag, due to its high reactivity and close reactions.

\subsubsection{Summary of Lime Quality for Steel}

In summary, the lime quality for steel applications must be monitored using limestone chemistry and petrography to control the calcination including adapted gradation and fuel use to allow for suitable chemistry, reactivity, and adapted granulometry.

An example of the effect of limestone chemistry on quicklime chemistry is given in Table 2. Calcination results in the concentration of impurities because of $\mathrm{CO}_{2}$ release. It can be noted that part of the limestone remains in a carbonate form, and that sulphur increases more than it does by concentration, probably due to the fuel used in releasing sulphur.

To illustrate as example the effect of calcination on the specific surface of lime, influencing its reactivity, scanning electron microscopy (SEM) pictures have been taken at the same scale (see Figure 4), of quicklime samples at different rates of calcination, showing the significant changes in crystals and pores sizes.

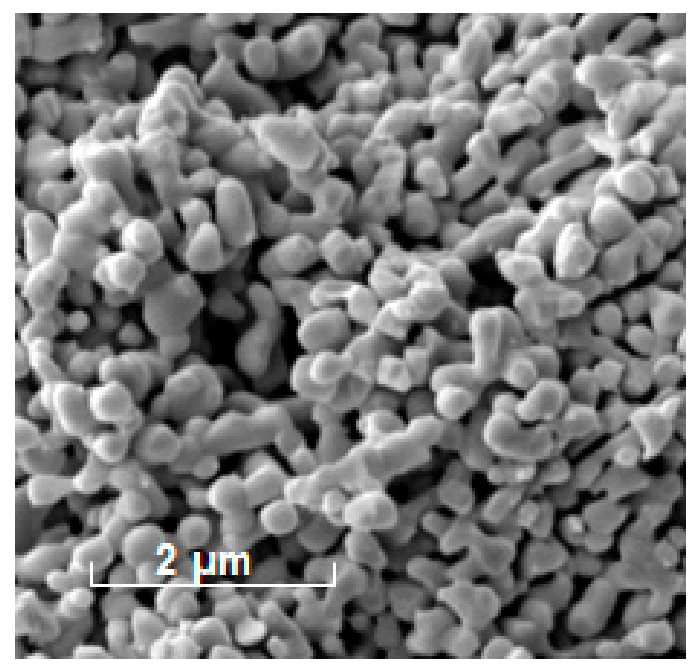

(a)

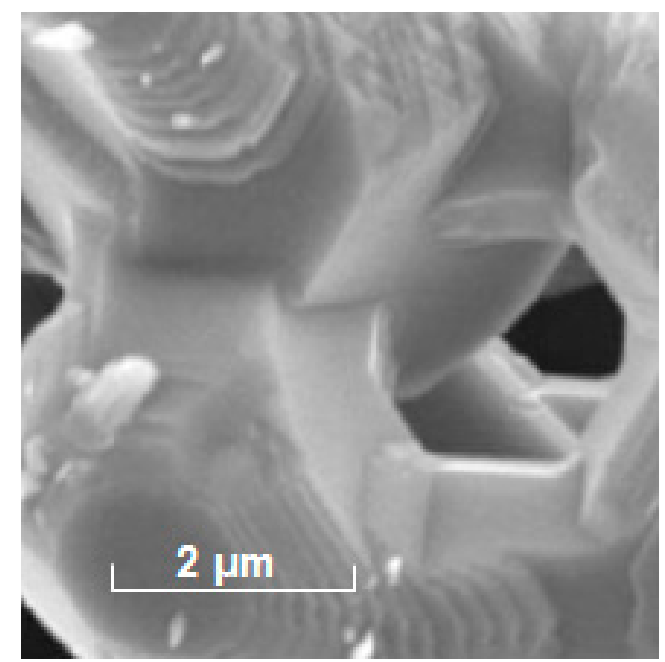

(b)

Figure 4. Scanning electron microscopy $($ SEM) pictures of quicklime $(\times 10.000)$. (a) Soft burnt, (b) Hard burnt. 
Table 2. Limestone and the resulting quicklime chemical analysis after calcination in a kiln.

\begin{tabular}{ccc}
\hline Chemical Content & Limestone & Quicklime \\
\hline $\mathrm{CaO}(\%)$ & 54.51 & 93.68 \\
$\mathrm{CO}_{2}(\%)$ & 42.78 & 1.50 \\
$\mathrm{MgO}(\%)$ & 0.95 & 1.66 \\
$\mathrm{SiO}_{2}(\%)$ & 0.05 & 0.09 \\
$\mathrm{~S}(\%)$ & 0.047 & 0.106 \\
\hline
\end{tabular}

\subsection{Engineered Lime Products for Environmental Applications}

The lime industry has developed a large range of products that are dedicated for their usage in different applications. The steel industry, beside its main processes, must also manage different utilities, leading to some specific needs, especially in environmental management.

The steel industry is an intensive energy user, using various fuels as required by processes, and based on techno-economic reasons. Fuel combustion generates flue gases with pollutants, including sulphur and/or chlorine. Lime helps to comply with increasingly stricter regulations on emission levels. Special lime-based product solutions are available for sinter plants, coke ovens, and boilers. These solutions are customized for iron- and steelmaking processes and emissions. Powdered limestone is used for boiler flue gas desulphurization, and high specific surface hydrate is now recognized as an efficient technology for the desulphurization of sinter gases, as it meets new, stricter emission norms.

Lime-based products also provide a good range of solutions for residual sludge and solid waste treatments. Lime reactivity and alkalinity, combined with possible pozzolanic reactions, can allow for both the solidification and the insolubilization of contaminants. It can also be used in the processing of by-products, assisting in dehydration and granulation. Lime is also efficient for sanitizing and stabilizing sewage sludges, which also allows to recycle in agriculture.

Lime acts as the first necessary step to remove dissolved metals from wastewater, and it neutralizes free acids in water. Water treatment meets the requirement that is necessary for its discharge from iron- and steelmaking plants. Hydrated lime in the form of lime slurry is used to balance hardness; for example, for use in heating systems or for use in final steel product washing to prevent carbonate deposition [13].

\section{Importance of Lime or/and Dolime in the Production of Quality Steel}

\subsection{Introduction}

Lime is an essential and critical raw material for steelmaking. The science of lime product interaction with the various fluxing components during sintering, melting, and ladle refining has become the basis for understanding the old phrase "Make the slag and the steel will make itself".

Raw materials, including iron ore, coal, and scrap are typical sources of undesirable residuals such as sulphur, phosphorus, silicon, and various oxides. Lime, in very simple terms, helps to remove these impurities, to an extent. The time, efficiency, and effectiveness of the reactions depends on lime quality, among many other factors.

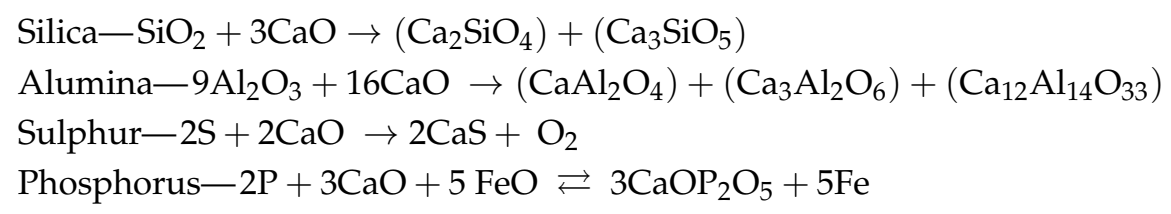

The clean steel process starts from the early stage of iron making, and the process becomes critical towards the last stages in the secondary metallurgical process [14]. The lime selection process plays a very important role in defining the productivity, quality, and cleanliness from sintering stage to 
steel melting, and finally the secondary metallurgy process (Table 3). Lime characteristics and process control are critical to cleanliness, such as:

- Removing sulphur at the hot metal desulphurization station;

- Phosphorous removal in the BOF;

- Foamy slag preventing nitrogen and hydrogen pickup during melting in the EAF;

- Avoiding over-oxidation of steel during steel melting in EAF and BOF;

- De-oxidation and desulphurization practices in the secondary metallurgy treatment.

\subsection{Lime Product Characteristics for Iron-and Steelmaking Process Steps}

The various process steps, which perform several critical functions in steelmaking, require different characteristics of lime to enhance their efficiency and effectiveness (Table 3).

Table 3. Lime characteristics for iron- and steelmaking.

\begin{tabular}{|c|c|c|c|}
\hline Process Step & Lime and Dolime Requirements & Critical Parameters & $\begin{array}{l}\text { Typical Consumption } \\
\text { (kg/t of Steel) }\end{array}$ \\
\hline Sinter Plant & $\begin{array}{l}\text { - Limestone-Grain size suitable } \\
\text { for dosing (0-3mm), High } \mathrm{CaO} \\
\text { (56\%), and lower impurities } \\
\text { - Burnt lime-High } \mathrm{CaO} \text { and low } \\
\text { impurities, controlled reactive }\end{array}$ & $\begin{array}{l}\text { - } \quad \text { Grain size } \\
\text { - } \quad \mathrm{MgO} \text { content }\end{array}$ & $\begin{array}{l}\text { - Limestone: } 100-150 \\
\text { - } \quad \text { Lime: 0-25 }\end{array}$ \\
\hline $\begin{array}{c}\text { Hot Metal } \\
\text { Desulphurization }\end{array}$ & $\begin{array}{l}\text { - Fluidized lime (<90 microns) } \\
\text { High } \mathrm{CaO} \text {, low impurities }\end{array}$ & $\begin{array}{lc}\text { - } & \text { Flowability } \\
\text { - } & \text { Reactivity }\end{array}$ & - Lime: 5-10 \\
\hline BOF Converter & $\begin{array}{ll}\text { - } & \text { Lump lime, Dolime ( } 5-50 \mathrm{~mm}) \\
\text { - } & \text { Lime fines for injection }(<12 \mathrm{~mm})\end{array}$ & $\begin{array}{ll}\text { - } & \text { High } \mathrm{CaO} \\
\text { - } & \text { Soft burnt lime } \\
\text { - } & \text { Lower fines }\end{array}$ & $\begin{array}{ll}\text { - } & \text { Lime: } 40-70 \\
\text { - } & \text { Dolime: 0-40 }\end{array}$ \\
\hline $\begin{array}{l}\text { Electric Arc } \\
\text { Furnace }\end{array}$ & $\begin{array}{l}\text { - Lump lime, Dolime }(5-50 \mathrm{~mm}) \\
\text { - } \quad \text { Lime Injection }(0-12 \mathrm{~mm})\end{array}$ & $\begin{array}{ll}\text { - } & \text { High } \mathrm{CaO} \\
\text { - } & \text { Lower fines } \\
\text { - } & \text { Flowability }\end{array}$ & $\begin{array}{l}\text { - Lime: } 0-50 \\
\text { - } \quad \text { Dolime: 0-50 }\end{array}$ \\
\hline $\begin{array}{l}\text { Secondary } \\
\text { Metallurgy }\end{array}$ & $\begin{array}{l}\text { - Lump lime }(5-20 \mathrm{~mm}) \\
\text { - } \quad \text { Lime Injection }\end{array}$ & $\begin{array}{ll}\text { - } & \text { Metallurgical reactivity } \\
\text { - } & \text { Low } \mathrm{H}_{2} \mathrm{O} \\
\text { - } & \text { Low carbon for } \\
& \text { stainless steel }\end{array}$ & $\begin{array}{ll}\text { - } & \text { Lime: } 5-10 \\
\text { - } & \text { Dolime: } 0-5\end{array}$ \\
\hline
\end{tabular}

\subsubsection{Agglomeration and Sintering}

The quality, granulometry, quantity, and method of lime addition to the agglomeration process are critical to sinter performance and productivity. The granulometry is important for the creation of uniform blending, which impacts the permeability of the charge, and hence the associated burning and heat transfer conditions during sintering. Burnt lime, as compared to limestone, improves the heat transfer in the sintered layer. At the same basicity and the same volume of fuel, a change in the $\mathrm{CO}_{2} / \mathrm{CO}$ ratio can occur, due to the different amounts of carbonates after their replacement by lime. Lime dosing during agglomeration could potentially increase the sinter productivity by about $20 \%$, reducing the cost per ton, and reducing the return sinter $[15,16]$. 


\subsubsection{Hot Metal Desulphurization}

The industry gradually moved from the use of calcium carbide (in Europe) and soda ash (Japan) to co-injection of pulverized lime and magnesium metal in the Kanbara refining station, due to its higher effectiveness with removing sulphur, the production cost, and the environmental benefits. The powder injection rate, the residence time of the powder in the plume, and the particle size, are the critical parameters influencing the desulphurization rate. Hence, the selection of an appropriate fluidizing agent (siloxanes based) and granulometry (powder particle size) is critical to achieving the flowability of lime and dense phase injection, affecting the effectiveness of the reagents and minimizing the iron droplets in the slag, hence improving the hot metal yield [17]. A Lower sulphur content in the lime particles is an added advantage.

$$
\begin{aligned}
{[\mathrm{S}]+\mathrm{CaO} } & \rightarrow \mathrm{CaS}+[\mathrm{O}]\left(\Delta \mathrm{G}^{0}=115,358-38.66 \mathrm{~T}[\mathrm{~J} / \mathrm{mol}]\right) \\
& \mathrm{Mg}+\mathrm{CaO}+\mathrm{S} \rightarrow \mathrm{CaS}_{(\mathrm{s})}+\mathrm{MgO}_{(\mathrm{s})}
\end{aligned}
$$

\subsubsection{BOF Converter Process}

Lime addition in the BOF is important to protecting refractories, and maintaining alkalinity for assisting in dephosphorization. While oxygen lancing facilitates the removal of carbon from the bath as $\mathrm{CO}$, other elements, including $\mathrm{Si}, \mathrm{Mn}$, and $\mathrm{P}$, also oxidize and are absorbed in the slag layer $[18,19]$. Top-blown converters typically use lump lime, using conveyors, while bottom-blown converters add pulverized lime through tuyeres. Lime addition through top-blown lances are used in Japan, while still remaining a challenge in the European and US industries. According to Behrens, Koenitzer and Kootz [20], soft burnt lime, having a large specific surface and good reactivity, favors dephosphorization and desulphurization. Higher quality lime facilitates a lower consumption of lime and an improvement in steel melt shop productivity.

\subsubsection{Electric Arc Furnace Process}

There has been a lot of research on foamy slag practice in EAFs. The foamed slag helps to stabilize the arc, protecting the refractories from the arc, shielding the metal from the atmosphere, and improving the energy efficiency by reducing the power-on time and the repair time. Foaminess also helps in improving the chromium recovery, in the case of stainless steel melting. CO gas caused by the reaction of carbon and oxygen $(\mathrm{FeO})$ helps foam bubbles to form on the top of a dense layer of slag. The slag composition is of great importance, with an overall requirement of a limited amount of second-phase particles serving as gas nucleation sites [21]. Lime $(\mathrm{CaO})$ injection foaminess to be maintained throughout the heating phase, and the second-phase particles serve to control the apparent viscosity of the slag, which is a parameter of paramount importance to profitably control the slag foaming. It is also important to saturate the slag by $\mathrm{MgO}$, by the use, for instance, of dolime. $\mathrm{MgO}$ saturation is fundamental to ensure that enough solid particles to promote the foaming and chemical equilibrium toward the refractory lining.

$$
\mathrm{FeO}_{(\mathrm{s})}+\mathrm{C}_{(\mathrm{s})} \rightarrow \mathrm{Fe}_{(\mathrm{l})}+\mathrm{CO}_{(\mathrm{g})}
$$

\subsubsection{Secondary Metallurgy}

Secondary metallurgy treatment is the last process step in handling, refining the liquid metal, and acting as a buffer between the melting furnace and casting. The quality of the raw materials added during the process is critical, as there is no extraction process thereafter. The white slag, high basicity, and low oxygen ppm during the process is able to absorb inclusions, give a slag coating on the refractories, and reduce sulphur content in the liquid steel [22]. Correct granulometry and the 
chemistry of the lime helps to develop the white slag in the early stages of the process, enabling the production of cleaner steel [23].

\section{Lime Handling and Addition Practices}

As briefed above, a variety of lime, dolime, and blended lime products are used during iron- and steelmaking process. In the BOF and EAF, it is common to see high-calcium lump lime and dolomitic lump lime being charged over the roof in a bucket, or through some type of feed system.

The controlled addition of lime and dolime in the iron- and steel-making processes is gaining importance. Controlled dosing of lime in the sinter raw feed enhances productivity and reduces cost. New technologies such as sidewall lime injection facilitate direct feed into the slag/metal interface, optimizing the foamy slag characteristics. Lime injection helps in maintaining a foamy slag in the EAF during the entire heat cycle, and it provides multiple benefits, including environmental compliance, reduction in consumption, lower slag volumes, better metallic yield, and higher productivity. Lime injection in the BOF has also been successfully tried and used at many steel plants. Controlled lime addition is also equally important in secondary metallurgy, to make slag that ensures good quality steel for smooth casting that is free of inclusions.

\subsection{Sinter Plant Lime Dosing}

It is a common practice to add fine lime $(0-3 \mathrm{~mm})$ into the sinter feed to improve the productivity, fuel consumption, permeability, and the sinter cold strength [16]. Lime fines help in improving granulation and micro-pellet resistance during sintering, and it increases the vertical sintering speed while reducing the specific consumption of the limestone in sinter making. Lime addition timings, especially considering the reactivity of lime and its maturation (20-60 $\mathrm{min})$, is critical for increasing the sinter productivity.

We conducted a study on the impact of lime quality and granulometry selection on the sintering efficiency [24]. We have observed a significant effect on the productivity, fuel consumption, and sinter fractions. The research revealed an approximately $27 \%$ increase in productivity using engineered limes compared to the reference (Figure 5).

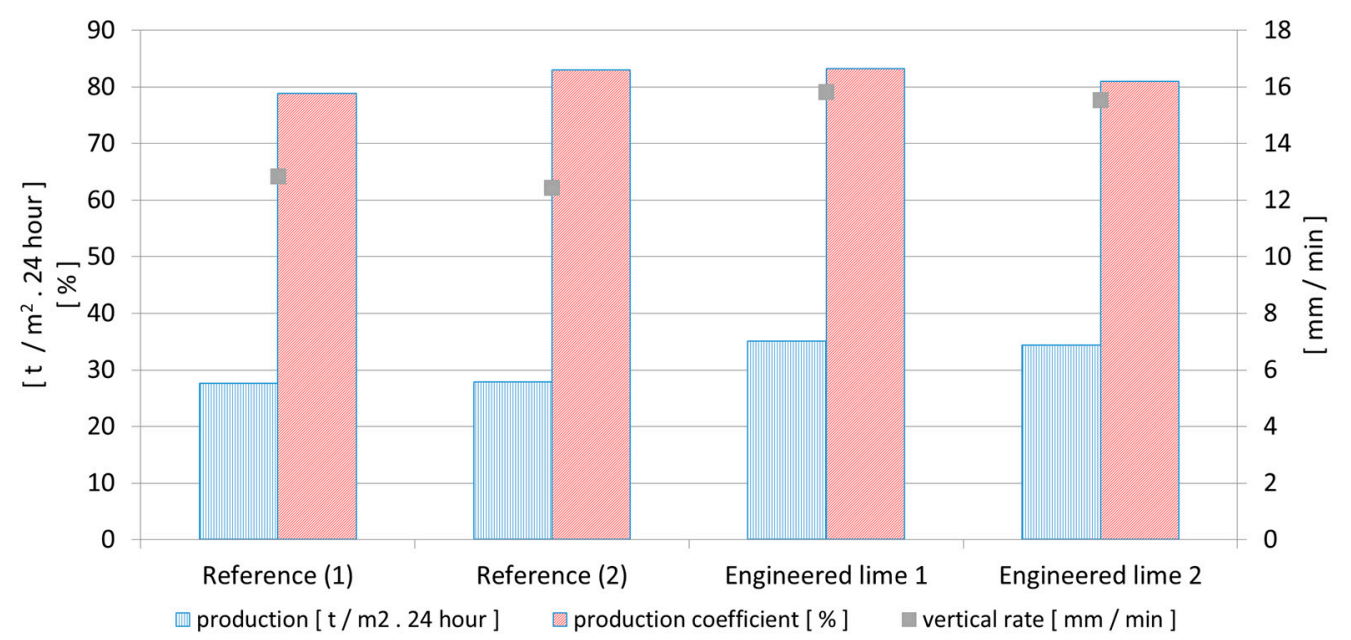

Figure 5. Impact of lime selection on sinter properties.

In a research conducted by the Research Fund for Coal and Steel on the "Impact of burnt lime on the sintering process", it was demonstrate that lime quality affects sinter productivity [16]. The steel plants could work to optimize the method of using and injecting burnt lime in sinter plants, depending on the lime quality. 


\subsection{BOF Lime Injection}

Early lime injection trials were conducted back in the 1980s, but these had difficulties due to the lime characteristics and the oxygen lance design limitations. Lime injection through bottom concentric tuyeres in OBM/Q-BOP (from the German "Oxygen Bodenblasen Maxhuette" or "Quick-Quiet Bottom Oxygen blowing Process" in North America) has been successful, but most of the shops still top charge the lump lime in the converter. Carmeuse tried an injection concept through a top lance in 2011 at a North American steel mill (Figure 6). Lime (in white in Figure 6) was injected through a centered additional hole, together with oxygen (in blue in Figure 6) using a specifically designed lance. The benefits perceived are $100 \%$ recovery of the lime injected, improved dissolution rate of the lime, consistently better slag, improved dephosphorization, reduced slopping, elimination of reblows due to phosphorus, and improvement in the refractory lining life [25].

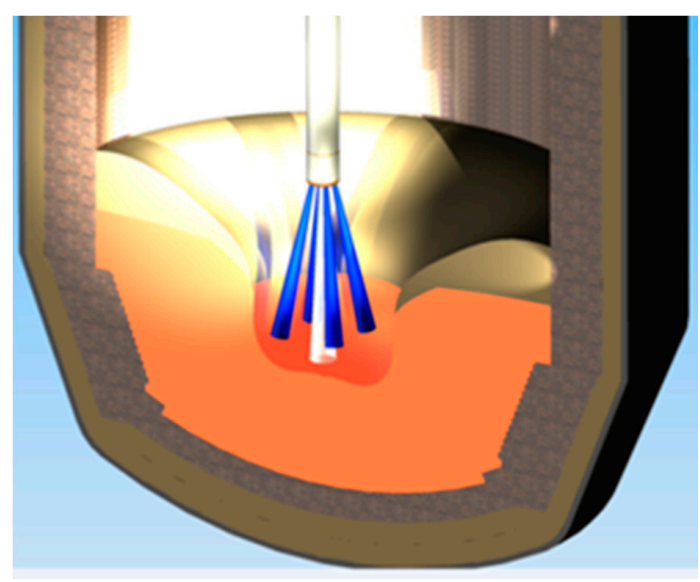

Figure 6. Lime injection in BOF.

\subsection{EAF Lime Injection}

The EAF slag composition changes dynamically throughout the heating process. Lime addition through bucket route or a fifth hole poses various challenges to the steel melter in controlling the foaminess of the slag. Lime injection through the sidewall (Figure 7) facilitates immediate controls on slag viscosity and related parameters, sustaining foaminess during the entire process. Lime injection and control on foaminess saves on power-on time, energy consumption, refractories, and lime consumption, and allows for a safer and better environment [26].

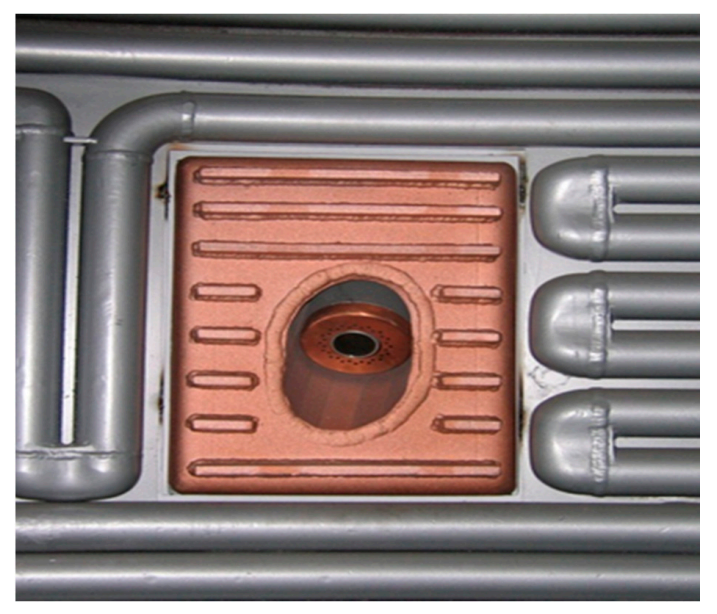

Figure 7. Lime injection in an electric arc furnace (EAF)—side wall lance. 


\section{Impact of Lime Chemistry on Use of Lime and Steel Process Parameters}

The slag properties and chemistry are important for lowering sulphur levels and trapping inclusions that are transported to the slag. Various steel quality levels also require different conditions in the slag, which can be adjusted with proper lime addition. It is then very important to pay attention to the chemical and physical properties of lime [27].

\subsection{CaO Content in Lime}

Quite often, steel plants are unclear in their specifications about total $\mathrm{CaO}$ and available $\mathrm{CaO}$ content. The stone quality and calcination process affects the available $\mathrm{CaO}$ content in lime. The higher the inert amount, the lower the amount of $\mathrm{CaO}$ content, and similarly, high residual $\mathrm{CO}_{2}$ content means a lower amount of total and available $\mathrm{CaO}$ content (Table 4). Sulphur contamination during calcinations will react with the $\mathrm{CaO}$ to form $\mathrm{CaSO}_{4}$, and affect the available $\mathrm{CaO}$ content in lime. Each percent of additional $\mathrm{CaO}$ that is available potentially saves about a kilo per ton of total lime requirements for heating, reducing costs and improving productivity.

Table 4. Lime characteristics depending on stone quality and residual $\mathrm{CO}_{2}$.

\begin{tabular}{llll}
\hline Stone Quality: & Inerts = 1\% & $\mathbf{M g C O}_{\mathbf{3}}=\mathbf{1} \%$ & $\mathrm{CaCO}_{\mathbf{3}}=\mathbf{1} \%$ \\
\hline Res. $\mathrm{CO}_{2}$ & $\mathrm{CaO}$ av. & $\mathrm{CaO}$ tot. & \\
$1.5 \%$ & $94.01 \%$ & $95.82 \%$ & \\
$2.0 \%$ & $92.88 \%$ & $95.33 \%$ & \\
$5.0 \%$ & $86.13 \%$ & $92.41 \%$ & \\
$8.0 \%$ & $79.39 \%$ & $89.49 \%$ & \\
$10.0 \%$ & $74.89 \%$ & $87.54 \%$ & \\
\hline Stone Quality: & Inerts $=\mathbf{2} \%$ & $\mathbf{M g C O}=\mathbf{1} \%$ & $\mathbf{C a C O}_{\mathbf{3}}=\mathbf{1} \%$ \\
\hline Res. $\mathrm{CO}_{2}$ & $\mathrm{CaO}$ av. & $\mathrm{CaO}$ tot. & \\
$1.5 \%$ & $92.34 \%$ & $94.15 \%$ & \\
$2.0 \%$ & $91.22 \%$ & $93.67 \%$ & \\
$5.0 \%$ & $84.52 \%$ & $90.80 \%$ & \\
$8.0 \%$ & $77.83 \%$ & $87.93 \%$ & \\
$10.0 \%$ & $73.36 \%$ & $86.02 \%$ & \\
\hline
\end{tabular}

\subsection{Silica $\left(\mathrm{SiO}_{2}\right)$ Content in Lime}

Acidic contents, mainly $\mathrm{SiO}_{2}$ and $\mathrm{Al}_{2} \mathrm{O}_{3}$, originated from the raw materials, and previous processes steps determine the amount of $\mathrm{CaO}$ required. Any impurities from lime, including $\mathrm{SiO}_{2}$, is a burden to the process, as an extra amount of lime will be required to remove the inherent silica. It also lowers the yield. Every extra percent of $\mathrm{SiO}_{2}$ coming from lime would demand between two and four kilograms of extra lime per ton of steel. This will cause about 5-10 grams of iron to be lost to the slag as FeO. The total opportunity losses would include extra melting (energy and productivity), plus yield loss, simply calculated by multiplying the $\mathrm{FeO} \%$ by 0.78 .

\subsection{Sulphur Content in Lime}

Sulphur is the most undesirable impurity in steel, and its removal may not be economically feasible without the use of high calcium lime during either hot metal desulphurization or secondary metallurgical treatment $[17,22]$ :

$$
[\mathrm{S}]_{\text {metal }}+\left(\mathrm{O}^{2-}\right) \rightleftarrows[\mathrm{O}]_{\text {metal }}+\left(\mathrm{S}^{2-}\right)_{\text {slag }}
$$

The desulphurization improves with an increase in the concentration of calcium oxide until it reaches the saturation limit (mass \% of 55-60), and beyond that, the desulphurization rate is limited. The rate of sulphur removal $\left(\% S_{\text {initial }}-\% S_{\text {final }}\right) /\left(\% S_{\text {initial }}\right)$ is determined by the sulphide capacity, 
the stirring intensity, and the slag volume. The sulphide capacity of the slag depends on the oxides in the slag (basicity), the volume and viscosity of the slag, and the temperature and the available sulphur content in the slag. Slag enrichment with extraneous sulphur such as contaminated lime is highly undesirable as it may affect the slag absorption capacity [12].

To understand the impact of lime quality on desulphurization, we conducted a detailed study at a steel mill before making a decision to switch from low quality lime to high $\mathrm{CaO}$ lime. The results summarized in Table 5 clearly reflect that high $\mathrm{CaO}$ lime improves the sulphide capacity and the final sulphur level in steel.

Table 5. Impact of lime quality on sulphide capacity and final sulphur content in steel.

\begin{tabular}{lll}
\hline Lime Quality: & & \\
\hline Lime characteristics & $\mathrm{A}(10$ heats $)$ & $\mathrm{B}(10$ heats $)$ \\
\hline Average $\mathrm{CaO}$ & $85.7 \%$ & $94.3 \%$ \\
Average $\mathrm{MgO}$ & $0.5 \%$ & $0.5 \%$ \\
Average $\mathrm{SiO}_{2}$ & $1.6 \%$ & $1.0 \%$ \\
\hline Ladle Slag results & & \\
\hline Calculated sulphide capacity & -2.42 & -2.32 \\
Initial sulphur in steel & $0.039 \%$ & $0.041 \%$ \\
Final sulphur in steel & $0.016 \%$ & $0.013 \%$ \\
\hline
\end{tabular}

\subsection{Loss on Ignition}

Loss on ignition depicts the total weight loss that is associated with water and carbon dioxide evolutions, quantified by recording the sample weights before and after controlled heating. The soft burnt lime with about 3\% LOI, produced under controlled condition, is reactive and ideal for steelmaking process, while hard burnt lime with low LOI is difficult to dissolve in the steel bath [28,29]. Higher LOI $(>2 \%)$ indicates that both or either moisture and carbon dioxide content are on the higher side and undesirable in the steelmaking process. Higher and inconsistent LOI may affect the quality (hydrogen), the cost of steel (energy to calcinate stone), the productivity (extra time needed to input energy), and most importantly the safety (boil, splashing) in a steel mill.

\subsection{Granulometry (Grain Size)}

Grain size control is very important for all raw materials that are fed into iron- and steelmaking processes. Steel producers decide the size range based on the infrastructure, dissolution rate, environmental controls, and yield. The finer size $(0-3 \mathrm{~mm})$ is ideal for sinter plants, mainly for the homogeneity of the sinter feed. Since a negative pressure is maintained in BOFs and EAFs, to avoid the fines being sucked through the fume exhaust system, and based on the conveyor designs, a coarser size $(10-50 \mathrm{~mm})$ is mainly good for the steel melting process. A rather quicker dissolution during tapping and at the secondary metallurgy station, demands a size of between 5 and $20 \mathrm{~mm}$. Most of the steel mills are gradually moving towards lime injection in BOFs and EAFs, as this brings huge benefits on environmental compliance, savings on lime consumption, and significant controls on the slag making practices.

\section{Summary}

Slag making is critical to steelmaking. The control of raw materials is equally important at the initial stages of agglomeration as at the final stages in steelmaking. Lime and dolime are the most economical and environmentally friendly fluxes, acting as an antidote to impurities, and helping to clean the steel and protecting refractories. The lime characteristics and requirements vary for each processing step during iron- and steelmaking. Lime fines act as a cement in the agglomeration process, lump or injection lime helps to maintain the alkalinity and the removal of phosphorus during the 
BOF process, and lime injection supports a consistently good foamy slag throughout the process. High-calcium soft-burnt lime with the lowest possible level of impurities potentially improves the productivity (process time \& refractory life), reduces cost (reduced lime consumption), improves metallic yield (reduced slag volumes), cleans the steel (less impurities), improves safety (reduced slopping), and provides better environment in the steel shop.

Author Contributions: F.P. and S.M. did the original draft preparation. F.P. and S.M. wrote the paper and revised the manuscript.

Funding: This review received no external funding

Conflicts of Interest: The authors declare no conflict of interest.

\section{References}

1. Alaabed, S.; Soltan, M.A.; Abdelghany, O.; Amin, B.E.M.; Tokhi, M.E.; Khaleel, A.; Musalim, A. United Arab Emirates limestones: Impact of petrography on thermal behaviour. Mineral. Petrol. 2014, 108, 837-852. [CrossRef]

2. Boynton, R.S. Chemistry and Technology of Lime and Limestone, 2nd ed.; John Wiley \& Sons Inc.: Hoboken, NJ, USA, 1980; ISBN 0-471-02771-5.

3. HaiDo, D.; Specht, E.; Kehse, G.; Ferri, V.; Christiansen, T.L.; Bresciani, P. Simulation of lime calcination in PFR kilns-Influence of source and size of limestone. ZKG Int. 2012, 4, 56-65.

4. Fuessl, E.; Jahn, F. 25 Years of industrial development on the parallel flow regenerative lime shaft kilns. ZKG Int. 1982, 35, 290-296.

5. Vola, G.; Sarandrea, L.; Della Porta, G.; Cavallo, A.; Jadoul, F.; Cruciani, G. The influence of petrography, mineralogy and chemistry on burnability and reactivity of quicklime produced in Twin Shaft Regenerative (TSR) kilns from Neoarchean limestone (Transvaal Supergroup, South Africa). Mineral. Petrol. 2018, 112, 555-576. [CrossRef]

6. Gaye, H.; Riboud, P.V. Lime in oxygen steelmaking. Prospects of its consumption and quality requirements. Rev. Met. Paris 1983, 80, 475-482. [CrossRef]

7. Campbell, A.J. Lime calcination: Time and temperature of calcination expressed as a single variable and the effect of selected impurities on lime properties. Zement-Kalk-Gips 1988, 9, 442-446.

8. Potgieter, J.H.; Potgieter, S.S.; Moja, S.J.; Mulaba-Bafubiandi, A. The standard reactivity test as a measure of lime's quality. J. S. Afr. Inst. Min. Metall. 2002, 102, 67-69.

9. Deng, T. Study on the Dissolution of Lime and Dolomite in Converter Slag. Ph.D. Thesis, Division of Micro Modeling Department of Material Science and Engineering Royal Institute of Technology (KTH), Stockholm, Sweden, 2012.

10. Moropoulou, A.; Bakolas, A.; Aggelakopoulou, E. The effects of limestone characteristics and calcination temperature to the reactivity of the quicklime. Cem. Concr. Res. 2001, 31, 633-639. [CrossRef]

11. Mullins, R.C.; Hatfield, J.D. Effects of calcination conditions on the properties of lime. In The Reaction Parameters of Lime; ASTM STP 472; American Society for Testing and Materials: West Conshohocken, PA, USA, 1970; pp. 117-131.

12. Heiia, A.A.; Howatand, D.D.; Jochen, P.R. The effect of the reactivity of lime on desulphurization efficiency in the basic oxygen furnace. J. S. Afr. Inst. Min. Metall. 1973, 73, 249-257.

13. Oates, J.A.H. Lime and Limestone Chemistry and Technology, Production and Uses; Wiley VCH Verlag, GmbH: Weinem, Germany, 1998.

14. Fruehan, R.J. The Making, Shaping and Treating of Steel, Steelmaking and Refining Volume, 11th ed.; The AISE Steel Foundation: Pittsburgh, PA, USA, 1998.

15. Di Giorgio, N.; Brace, D.; Bennett, A.; Wijekulasuriya, K. BlueScope Steel Australia New Zealand Steel Manufacturing Business. Reengineering Bluescope Steel's port kembla sinter plant for high productivity and reduced steelworks greenhouse emissions. In Proceedings of the Engineering a Better World, Sydney Hilton Hotel, NSW, Australia, 18-21 September 2011.

16. Van Loo, F.; Douce, J.-F.; Martinez Pacheco, M.; Evrard, M.; Pietruck, R.; Schmid, H. Improved Sinter Mix Preparation While Using Challenging Raw Materials (IMSIMI)_Final Report; Research Fund for Coal and Steel (European Commission EUR 27901 EN); European Commission: Brussels, Belgium, 2014. 
17. Schrama, F.N.H.; Beunder, E.M.; van den Berg, B.; Yang, Y.; Boom, R. Sulphur removal in ironmaking and oxygen steelmaking. Ironmak. Steelmak. Process. Prod. Appl. 2017, 44, 333-343. [CrossRef]

18. Obst, K.-H.; Stradtmann, J.; Ullrich, W.; König, G. Present Status and Technical Advances of Steelworks Lime for Basic Oxygen Furnaces in Germany. In The Reaction Parameters o] Lime; ASTM STP 472; American Society for Testing and Materials: West Conshohocken, PA, USA, 1970; pp. 173-192.

19. Obst, K.-H.; Stradtmann, J. The influence of lime and synthetic lime products on steel production. J. S. Afr. Inst. Min. Metall. 1972, 72, 158-164.

20. Behrens, K.F.; Koenitzer, J.; Kootz, T.; Macnamara, J. The Effects of Lime Properties on Basic Oxygen Steelmaking. JOM 1965, 17, 776. [CrossRef]

21. Pretorius, E. Foamy Slag Fundamentals and their Practical Application to Electric Furnace Steelmaking. In Proceedings of the Electric Furnace Conference Proceedings, New Orleans, LA, USA, 15-18 November 1998.

22. Hassal, G.J. Phosphorus and Sulphur Removal from Liquid Steel by Secondary Steel Making Operations; Commission of the European Communities Technical Steel Research; EUR 11222 EN; European Commission: Brussels, Belgium, 1988.

23. Conejo, A.N.; Lara, F.R.; Macias-Hernández, M.; Conejo, A.N.; Lara, F.; Macias-Hernández, M.; Morales, R. Kinetic Model of Steel Refining in a Ladle Furnace. Steel Res. Int. 2007, 78, 141-150. [CrossRef]

24. Findoràk, R.; Department of Ferrous and Foundry Metallurgy, Technical, University of Košice, Košice, Slovak Republic. Confidential research report: The influence of the addition of different types of lime on the sintering process and the quality of the agglomerate. Personal communication, March 2017.

25. Wolfe, L.D.; Brelowski, R.; McKinney, D.; Cooper, G.; Brand, M.; Valentas, L.; White, J. BOF Lime Injection-Past to Future. SCANMET IV. In Proceedings of the 4th International Conference on Process Development in Iron and Steelmaking, Lulea, Sweden, 10-13 June 2012; Volume 1.

26. Mombelli, D.; Barella, S.; Mapelli, C.; Gruttadauria, A.; Moreschi, R.; Marras, R.; Bruletti, G.; Frittella, P.; Mora, N.; Angelini, L. Evaluation of the effect of lime injection on the Electric Arc Furnace performances. In Proceedings of the ICS 2018: 7th International Congress on Science and Technology of Steelmaking: The Challenge of Industry 4.0, Venezia, Italy, 13-15 June 2018.

27. Sarna, S.K. Quality of Lime for Steelmaking in Converter. 2015. Available online: www.ispatguru.com (accessed on 25 June 2018).

28. Maruoka, N.; Ito, K.; Hayasaka, M.; Nogami, H. Effect of $\mathrm{CO}_{2}$ Content in Quicklime on Dissolution Rate of Quicklime in Steelmaking Slags. ISIJ Int. 2017, 57, 1684-1690. [CrossRef]

29. Maruoka, N.; Ishikawa, A.; Shibata, H.; Kitamura, S. Dissolution Rate of Various Limes into Steelmaking Slag. High Temp. Mater. Proc. 2013, 32, 15-24. [CrossRef] 